\title{
Covid-19: all non-urgent elective surgery is suspended for at least three months in England
}

\author{
Gareth lacobucci
}

The BMJ

NHS hospitals in England have been told to suspend all non-urgent elective surgery for at least three months from 15 April to help the service deal with the covid-19 pandemic.

Trusts are also advised to urgently discharge inpatients who are medically fit to leave. In addition, the NHS will block-buy capacity in independent hospitals within the next fortnight to "expand critical care capacity to the maximum," NHS bosses have said.

In a letter to NHS staff on 17 March, ${ }^{1}$ NHS England's chief executive, Simon Stevens, and its chief operating officer, Amanda Pritchard, said that these measures aimed to free up 30000 or more of the English NHS's 100000 general and acute beds, supplementing them with "all available" additional capacity.

"Covid-19 presents the NHS with arguably the greatest challenge it has faced since its creation," they said. "This is a time when the entire NHS will benefit from pulling together in a nationally coordinated effort."

The letter said that trusts had "full local discretion" to wind down elective activity over the next 30 days as they saw fit. Emergency admissions, cancer treatment, and other clinically urgent care should continue unaffected, it advised.

\section{Repurposing}

Community health providers must take "immediate full responsibility for urgent discharge of all eligible patients identified by acute providers on a discharge list," the letter added. It said that emergency legislation laid before parliament this week would ensure that eligibility assessments for people needing social care support did not delay discharge.

Purchasing extra capacity at private hospitals would mean that their staff and facilities were available for urgent surgery, "as well as for repurposing their beds, operating theatres and recovery facilities to provide respiratory support for covid-19 patients," the letter said.

It also set out the aim to prepare for and respond to large numbers of inpatients requiring respiratory support, saying that national efforts to boost the number of mechanical ventilators were "well under way."

Discussing the measures at a Health Select Committee hearing on 17 March, Stevens said that the NHS aimed to increase the number of available mechanical ventilators from around 8000 to just under 12000 in the next few weeks. "In addition to that, the prime minister has sought to bring new supply, and we have set an open ended goal for what that would be," Stevens said.

\section{Protective equipment}

Regarding personal protective equipment (PPE), the letter said that, despite a currently adequate national supply, the NHS was aware of local distribution issues. It has set up a dedicated helpline for staff concerned about PPE: 08009159964 or 0191 2836543 (email: supplydisruptionservice@nhsbsa.nhs.uk).

But Stevens acknowledged that the UK would have to "ramp up" PPE production to satisfy demand as the pandemic developed. "This is a challenge facing every country," he told the committee. "A lot of the Chinese supply has been disrupted, so we are going to need to ramp up domestic production of those items. Do we need to improve the distribution to every part of the service? We think so."

The letter also stipulated that refresher training for directly supporting patients with respiratory needs must be provided to all clinical and patient facing staff within the next fortnight.

It advised hospitals to segregate all patients with respiratory problems (including presumed covid-19 patients). This segregation should initially be between those with respiratory illness and other cases. Once test results are known, positive cases should be nursed in bays or wards.

\section{"Impossible decisions"}

The select committee chair, Jeremy Hunt, repeatedly pressed NHS England's leaders on the lack of guidance to doctors on what to do if they had to make "impossible decisions" about which patients to allocate to intensive care beds, as had happened in northern Italy.

Stephen Powis, NHS medical director, emphasised that the aim of the measures was to avoid such situations at all costs, but he said that the NHS would provide doctors with guidance.

He said, "The reason that we are expanding capacity and have been working with the government closely on the policies they have introduced is to ensure that we do everything that we possibly can, not to get into that circumstance. But, of course, nothing is certain in medicine and doctors have to make difficult decisions, and if that becomes the case we will support them locally and nationally.

"We want to work collectively and collaboratively with our colleagues. If [we get to that stage] — and I absolutely emphasise 
that that is a point we do not wish to get to-of course we will work collectively on guidance."

1 NHS England and NHS Improvement. Letter to chief executives of all NHS trusts and foundation trusts, CCG accountable officers, GP practices and primary care networks, and providers of community health services. $17 \mathrm{Mar} 2020$. https://www.england.nhs.uk/ coronavirus/wp-content/uploads/sites/52/2020/03/urgent-next-steps-on-nhs-response-tocovid-19-letter-simon-stevens.pdf.

Published by the BMJ Publishing Group Limited. For permission to use (where not already granted under a licence) please go to http://group.bmj.com/group/rights-licensing/ permissions 